\title{
Caloric Density of Loricariichthys platymetopon (Osteichthyes, Loricariidae) in the Upper Paraná River Floodplain, Brazil
}

\author{
Daniela Aparecida Garcia*, Evanilde Benedito and Alice Michiyo Takeda \\ Núcleo de Pesquisas em Limnologia; Ictiologia e Aqüicultura; Departamento de Biologia; Universidade Estadual \\ de Maringá; Av. Colombo, 5790; 87020-900; Maringá - PR - Brasil
}

\begin{abstract}
This study analyzed the muscle energy content (caloric density) of L. platymetopon captured at different sites of the Upper Paraná River floodplain, and potential relationships between the content and various environmental variables (water temperature, oxygen dissolved in water, food availability, relative numeric abundance) and biological variables (body size and reproductive cycle). Quarterly samplings from September 2006 to June 2007 in the lakes and rivers resulted in a sample of 739 specimens, whose muscle caloric density was determined using a calorimeter. Differences between the caloric averages of the males and females and among the different stages of gonadal development were not significant. Caloric density varied over time and space, with two seasonal variation trends. The intensity of the correlation between the caloric density and each environmental variable, as well as the type of correlation, varied according to the sampled site. Body size and reproductive cycle were not correlated with caloric density.
\end{abstract}

Key words: energy, detritivorous fish, direct calorimetry, muscle, floodplain

\section{INTRODUCTION}

The ecosystem of the Upper Paraná River floodplain features high biodiversity and a great variety of aquatic habitats, such as rivers, connected and disconnected lakes (Thomaz et al., 2004). The river's fluctuations in hydrometric levels, which result from the seasonality of rainfall, determine the seasonality of the biotic and abiotic factors, as well as maintaining river-plain connectivity (Thomaz et al., 1997).

Loricariichthys platymetopon Isbrücker and Nijssen, 1979 (Loricariidae, Siluriformes), one of the most abundant fish species in the plain (Reis et al., 2003; Gaspar da Luz et al., 2004), was selected as the object of this study. The presence of this species in the Upper Paraná River floodplain, upstream from the city of Guaíra, has been related with the construction of the Itaipu dam, which submerged the Sete Quedas waterfalls, which in turn constituted a natural barrier against dispersion (Reis and Pereira, 2000). As detritivores, $L$. platymetopon play an important ecological role, integrating the detritus chain, which is the main route for energy flow and matter cycling in ecosystems (Bowen, 1983; Fugi et al., 2001).

The body energy content of any given fish is a good indicator of its physiological condition, as it

*Author for correspondence: daapga@yahoo.com.br 
reflects the total effect of physiological and environmental factors on that organism. Given that fish are made up of water, proteins, lipids, carbohydrates, ash and non-protein nitrogen compounds, their energy content is, therefore, determined by their chemical composition (Cui and Wootton, 1988). This content represents a parameter for the bioenergetics model and quantification of the energy balance for a given species (Hansen et al., 1993; Pedersen and Hislop, 2001; Dourado and Benedito-Cecilio, 2005). Due to the scarcity of specific information on this topic for several species, generic and constant energy values are often used (Economidis et al., 1981; Pedersen and Hislop, 2001). This is seen as inadequate by some ecologists, as significant differences - both intra- and interspecific - have been detected in temperate and neotropical environments (Bryan et al., 1996; Paul et al., 1998; Pedersen and Hislop, 2001; Vismara et al., 2004; Santos et al., 2006).

The factors that alter the energy content of fish are classified as biotic (sex, gonadal development stage, reproductive activity, age, size, competition, predation, parasitism) and abiotic (availability of food resources, $\mathrm{pH}$, dissolved oxygen, salinity, temperature and velocity of water flow) (Dourado and Benedito-Cecilio, 2005), and most can vary in spatial and/or seasonal scale. In the studies on the energy content of fish, in addition to determining the energy content of fish, studies must relate this content to biotic and/or abiotic factors, with the objective of explaining intraspecific variability (Kelso, 1973; Foltz and Norden, 1977; Rogers, 1988; Bryan et al., 1996; Encina and GranadoLorencio, 1997; Paul et al., 1998; Vismara et al., 2004; Dourado et al., 2005; Hondorp et al., 2005; Pothoven et al., 2006; Tirelli et al., 2006). However, most of these studies refer to temperate species (Dourado and Benedito-Cecilio, 2005).

The objective of this work was to compare the muscle energy content (caloric density) of $L$. platymetopon at different sites of the Upper Paraná River floodplain, over several months (spatial and seasonal variability). The study also aimed to investigate the potential relationships between the energy content of this species with environmental variables (water temperature, dissolved oxygen in water, food availability, relative numeric abundance) and biological variables (body size and reproductive cycle).

\section{MATERIAL AND METHODS}

\section{Studied area and data collection}

The studied area comprised the stretch of the Upper Paraná River floodplain situated downstrean from the Porto Primavera dam and upstream from the Itaipu reservoir (Thomaz et al., 1997). In this stretch, quarterly samplings were taken between September 2006 and June 2007, at sites belonging to three subsystems. In the Baía subsystem, the following were sampled: Fechada lake (LFEC; disconnected), Guaraná lake (LGUA; connected) and Baía river (RBAI). In the Ivinhema system, the following were sampled: Zé Ventura lake (LVEN; disconnected), Patos lake (LPAT; connected) and Ivinhema river (RIVI). In the Paraná subsystem, the following were sampled: Garças lake (LGAR; connected lake) (Fig. 1). The collections of $L$. platymetopon were conducted using gillnets of various mesh sizes (from 2.4 to 8 $\mathrm{cm}$ between adjacent nodes), exposed for $24 \mathrm{~h}$, and inspected every eight hours. Each L. platymetopon specimen was measured $(\mathrm{mm})$ and weighed (gram). The sex and gonadal development stage were identified according to the criteria proposed and adapted by Vazzoler (1996). The stages considered were: rest (RES), beginning maturation (BMA), maturing (MAG), mature (MAT), semispent (SSP), spent (SPE) and recovery (REC). The gonad weight (gram) of each specimen also was determined.

Muscle samples from each specimen were extracted from the region near the dorsal fin insertion. The samples were then washed in distilled water and enclosed in aluminum foil, labeled and frozen. They were later dried in a greenhouse using forced ventilation $\left(60^{\circ} \mathrm{C}, 48 \mathrm{~h}\right)$ and macerated using a ball mill, in order to obtain a fine and homogenous powder. The caloric density of these samples (the energy content measured in kilocalories per gram of dry weight $\mathrm{kcal} / \mathrm{g}$ DW) was determined using a adiabatic calorimeter (model Parr 1261), in the Energy Ecology laboratory of the Research Nucleus in Limnology, Ichthyology and Aquaculture (NUPELIA) at the State University of Maringá.

Water temperature $\left({ }^{\circ} \mathrm{C}\right)$ was obtained from each collection site using a thermometer attached to a YSI portable digital oximeter, which was used to measure the dissolved oxygen in water $(\mathrm{mg} / \mathrm{L})$ (NUPELIA Basic Limnology Laboratory). The percentage of organic matter (live and dead) of the sediment (\%) was determined through the 
difference in weight of sediment samples, which were dried at $80^{\circ} \mathrm{C}$ in a greenhouse, prior to and after being calcined in a muffle furnace at $560^{\circ} \mathrm{C}$ for four hours (NUPELIA Zoobenthos Laboratory). The numeric relative abundance $(\mathrm{CPUE}=$ capture by unit effort) and gonadosomatic index (GSI) of the sampled specimens were calculated using the following formulas: CPUEnum = number of individuals / $1000 \mathrm{~m}^{2}$ gillnet for $24 \mathrm{~h}$ and GSI $=$ (gonad weight $/$ body weight) * 100 (NUPELIA Ichthyology Laboratory).

\section{Data analysis}

In order to verify whether caloric density differed among the collection sites and months, nonparametric unifactorial analyses of variance were conducted (5,000 randomizations-ECOSIM) (Gotelli and Enstminger, 2006), as the normality and homoscedasticity requirements were not met. Specimens belonging to both the sexes and different stages of gonadal development were grouped for these analyses, as there were no significant differences between the sexes and gonadal development stages at any of the collection sites. A significance level of $\alpha=0.05$ was adopted using the Bonferroni correction; values of $\mathrm{p} \leq 0.0125$ were considered significant (Table 1).

With the objective of investigating the potential relationships between the caloric density and environmental and biological variables, nonparametric correlation analyses were conducted (Kendall tau rank correlation), between the muscle caloric density of L. platymetopon (dependent variable) and the variables water temperature, dissolved oxygen, percentage of organic matter of sediment, numeric relative abundance, gonadosomatic index (GSI) and standard length of L. platymetopon, for each collection site. Computer software STATISTICA (version 7.1) was used for these analyses, in which a significance level of $\alpha=0.05$ was adopted, using the Bonferroni correction; correlation values of $\mathrm{p} \leq$ 0.008333 were considered significant.

The percentage of organic matter of the sediment, the gonadosomatic index and the standard length were used as indicators of the availability (quantity) of food resources in the environment (detritus and benthic organisms associated with detritus and sediment), the reproductive cycle and the body size of L. platymetopon, respectively.

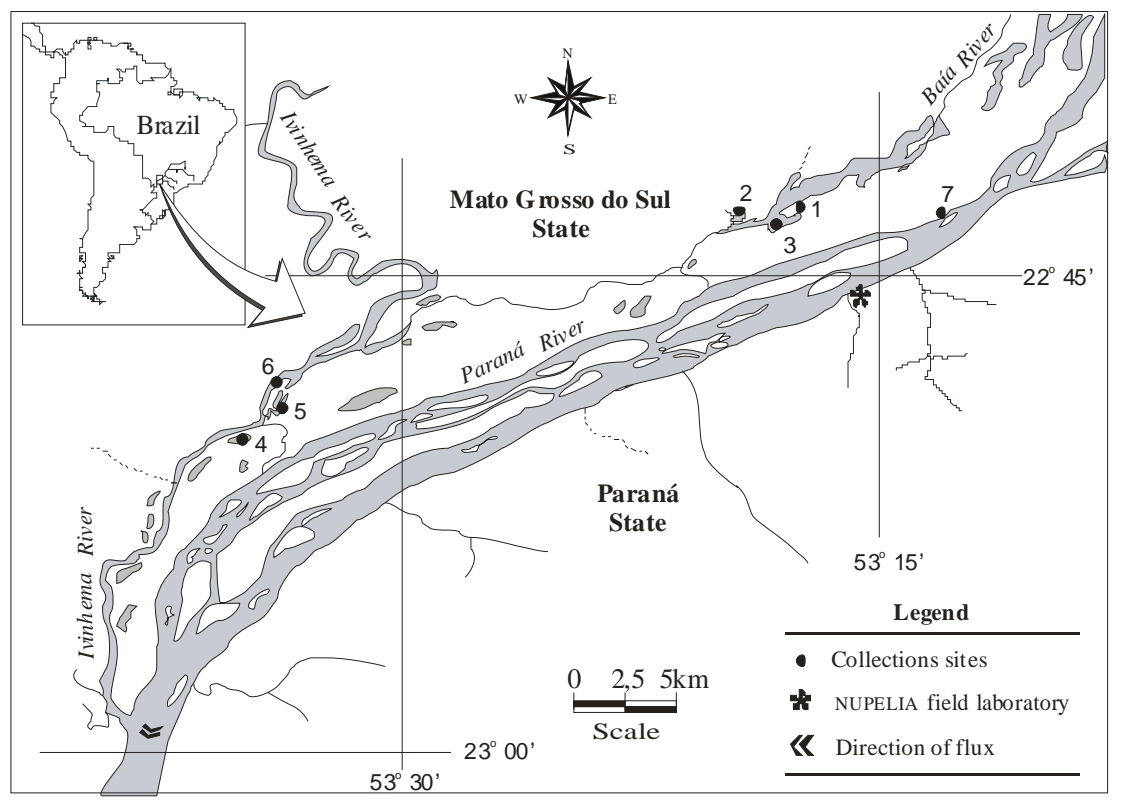

Figure 1 - Studied area and collection sites: (1) Fechada lake, (2) Guaraná lake, (3) Baía river, (4) Zé Ventura lake, (5) Patos lake, (6) Ivinhema river and (7) Garças lake. 
Table 1 - Result of the unifactor analyses of variance (F and p values) between sexes and among stages of gonadal development, at different sites of the Upper Paraná River floodplain. F = number of Loricariichthys platymetopon females used in the analyses, $\mathrm{M}=$ number of Loricariichthys platymetopon males used in the analyses. RES $=$ rest, $\mathrm{BMA}=$ beginning maturation, $\mathrm{MAG}=$ maturing, $\mathrm{MAT}=$ mature, $\mathrm{SSP}=$ semi-spent, $\mathrm{SPE}=$ spent, and $\mathrm{REC}=$ recovery. $(*)=\mathrm{p} \leq 0.0125$.

\begin{tabular}{|c|c|c|c|c|c|c|c|c|c|c|c|c|c|c|}
\hline \multicolumn{15}{|c|}{ Site } \\
\hline & \multicolumn{2}{|c|}{ LFEC } & \multicolumn{2}{|c|}{ LGUA } & \multicolumn{2}{|c|}{ RBAI } & \multicolumn{2}{|c|}{ LVEN } & \multicolumn{2}{|c|}{ LPAT } & \multicolumn{2}{|c|}{ RIVI } & \multicolumn{2}{|c|}{ LGAR } \\
\hline Stage & $\mathrm{F}$ & $\mathrm{M}$ & $\mathrm{F}$ & $\mathrm{M}$ & $\mathrm{F}$ & $\mathrm{M}$ & $\mathrm{F}$ & $\mathbf{M}$ & $\mathrm{F}$ & $\mathrm{M}$ & $\mathrm{F}$ & $\mathbf{M}$ & $\mathrm{F}$ & $\mathrm{M}$ \\
\hline RES & 3 & 1 & 17 & 2 & 21 & 12 & 11 & 2 & 8 & 0 & 5 & 2 & 14 & 1 \\
\hline BMA & 9 & 4 & 15 & 13 & 17 & 19 & 12 & 7 & 5 & 2 & 3 & 1 & 20 & 3 \\
\hline MAG & 4 & 9 & 5 & 24 & 10 & 29 & 0 & 13 & 3 & 12 & 4 & 0 & 7 & 21 \\
\hline MAT & 6 & 0 & 3 & 0 & 0 & 0 & 0 & 0 & 1 & 0 & 1 & 5 & 0 & 0 \\
\hline SSP & 39 & 17 & 49 & 51 & 27 & 28 & 3 & 10 & 4 & 4 & 9 & 0 & 49 & 16 \\
\hline SPE & 1 & 0 & 12 & 0 & 17 & 0 & 3 & 0 & 2 & 0 & 0 & 0 & 5 & 0 \\
\hline REC & 3 & 0 & 1 & 0 & 1 & 0 & 1 & 0 & 0 & 0 & 0 & 0 & 0 & 0 \\
\hline Total & 65 & 31 & 102 & 90 & 93 & 89 & 30 & 32 & 23 & 18 & 22 & 8 & 95 & 41 \\
\hline $\mathrm{F} ; \mathrm{p}(\operatorname{sex})$ & \multicolumn{2}{|c|}{$0.01 ; 0.90$} & \multicolumn{2}{|c|}{$1.83 ; 0.18$} & \multicolumn{2}{|c|}{$2.60 ; 0.10$} & \multicolumn{2}{|c|}{$0.08 ; 0.79$} & \multicolumn{2}{|c|}{$3.43 ; 0.07$} & \multicolumn{2}{|c|}{$0.15 ; 0.73$} & \multicolumn{2}{|c|}{$2.34 ; 0.12$} \\
\hline $\mathrm{F} ; \mathrm{p}(\mathrm{F})$ & \multirow{2}{*}{\multicolumn{2}{|c|}{$0.61 ; 0.69$}} & \multirow{2}{*}{\multicolumn{2}{|c|}{$1.86 ; 0.09$}} & \multirow{2}{*}{\multicolumn{2}{|c|}{ 1.98;0.09 }} & \multicolumn{2}{|c|}{$0.18 ; 0.94$} & \multicolumn{2}{|c|}{$0.60 ; 0.66$} & \multicolumn{2}{|c|}{$0.66 ; 0.60$} & \multicolumn{2}{|c|}{$1.16 ; 0.32$} \\
\hline $\mathrm{F} ; \mathrm{p}(\mathrm{M})$ & & & & & & & \multicolumn{2}{|c|}{$3.57 ; 0.03$} & \multicolumn{2}{|c|}{$1.40 ; 0.26$} & \multicolumn{2}{|c|}{$0.66 ; 0.49$} & \multicolumn{2}{|c|}{$0.74 ; 0.49$} \\
\hline
\end{tabular}

\section{RESULTS}

A total of 739 specimens of L. platymetopon were sampled in the Upper Paraná River floodplain, with amplitude in standard length varying between $130 \mathrm{~mm}$ (RBAI and RIVI) and $307 \mathrm{~mm}$ (LGUA) (Table 2).

Significant difference was recorded among the caloric averages of the sites (spatial variation) in the months of December 2006 and June 2007, although no pattern of spatial variation could be established.

The highest caloric averages were observed in December 2006 at LFEC, LGUA and LPAT; however, the same sites recorded the lowest averages in June 2007 (Fig. 2). The differences between the caloric averages of the different months was significant (seasonal variation) at LFEC, LGUA, RBAI and LPAT. Two distinct variation trends were recognized for the caloric density of L. platymetopon: one at LFEC and LGUA, in which peak muscle energy occured in December 2006, and another at RBAI and LVEN, with the peak occurring in March 2007. It was supposed that the trend featured at LPAT was the first one, and at RIVI and LGAR the second trend (Fig. 3).

Table 2 - Number of sampled specimens of Loricariichthys platymetopon $(\mathrm{n})$, average \pm standard deviation $(\overline{\mathrm{X}} \pm$ $\mathrm{SD}$ ) and amplitude (amp) in standard length, by collection site. LFEC = Fechada lake, LGUA = Guaraná lake, RBAI = Baía river, LVEN = Zé Ventura lake, LPAT = Patos lake, RIVI = Ivinhema river, and LGAR = Garças lake.

\begin{tabular}{cccc}
\hline Site & $\mathbf{n}$ & $\bar{X} \mathbf{+ S D}(\mathbf{m m})$ & $\mathbf{a m p}(\mathbf{m m})$ \\
\hline LFEC & 96 & $236 \pm 22,24$ & $155-294$ \\
LGUA & 192 & $229 \pm 24,91$ & $140-307$ \\
RBAI & 182 & $210 \pm 30,40$ & $130-278$ \\
LVEN & 62 & $227 \pm 27,94$ & $147-298$ \\
LPAT & 41 & $229 \pm 23,24$ & $187-281$ \\
RIVI & 30 & $209 \pm 35,17$ & $130-266$ \\
LGAR & 136 & $222 \pm 23,15$ & $145-273$ \\
\hline Total & 739 & & \\
\hline
\end{tabular}

Based on the result of the Kendall tau rank correlation analyses, it was observed that at LFEC, LGUA, RBAI and LPAT, the caloric density of the muscles of L. platymetopon was significantly correlated, basically, with the same variables (water temperature, dissolved oxygen, and percentage of organic matter in sediment); however, the significant correlations found at RBAI were weak. The correlation was positive between the caloric density and water temperature 
at LFEC, LGUA, RBAI and LPAT, and the dissolved oxygen in water was always negatively correlated with the caloric density in the muscles of $L$. platymetopon at these sites. The percentage of organic matter in the sediment was correlated with caloric density both positively (LFEC and LGUA) and negatively (RBAI and LPAT). The same occurred with the variable relative numeric abundance at LFEC (negative correlation) and LGUA (positive correlation) (Table 3).

Table 3 - Values of the Kendall-tau $(\tau)$ correlation coefficient, between caloric density and environmental and biological variables, by sampled site in the Upper Paraná River floodplain. TEMP $=$ water temperature, DO = dissolved oxygen, $\mathrm{OM}=$ percentage of organic matter, $\mathrm{CPUEnum}=$ relative numeric abundance, GSI = gonadosomatic index and Ls $=$ standard length. $(*)=\mathrm{p} \leq 0.008333$.

\begin{tabular}{cccccccc}
\hline \multicolumn{7}{c}{ Site } \\
\hline Variable & LFEC & LGUA & RBAI & LVEN & LPAT & RIVI & LGAR \\
\hline TEMP & $0.45^{*}$ & $0.57^{*}$ & $0.19^{*}$ & 0.19 & $0.50^{*}$ & -0.12 & 0.05 \\
DO & $-0.21^{*}$ & $-0.57^{*}$ & $-0.19^{*}$ & -0.19 & $-0.50^{*}$ & 0.12 & 0.08 \\
OM & $0.27^{*}$ & $0.60^{*}$ & $-0.18^{*}$ & -0.20 & $-0.50^{*}$ & 0.23 & -0.11 \\
CPUEnum & $-0.52^{*}$ & $0.61^{*}$ & 0.09 & -0.10 & 0.22 & -0.12 & -0.05 \\
GSI & 0.17 & 0.12 & 0.09 & -0.01 & 0.16 & 0.28 & 0.05 \\
LS & -0.09 & -0.06 & -0.04 & 0.07 & -0.03 & 0.35 & 0.06 \\
\hline
\end{tabular}
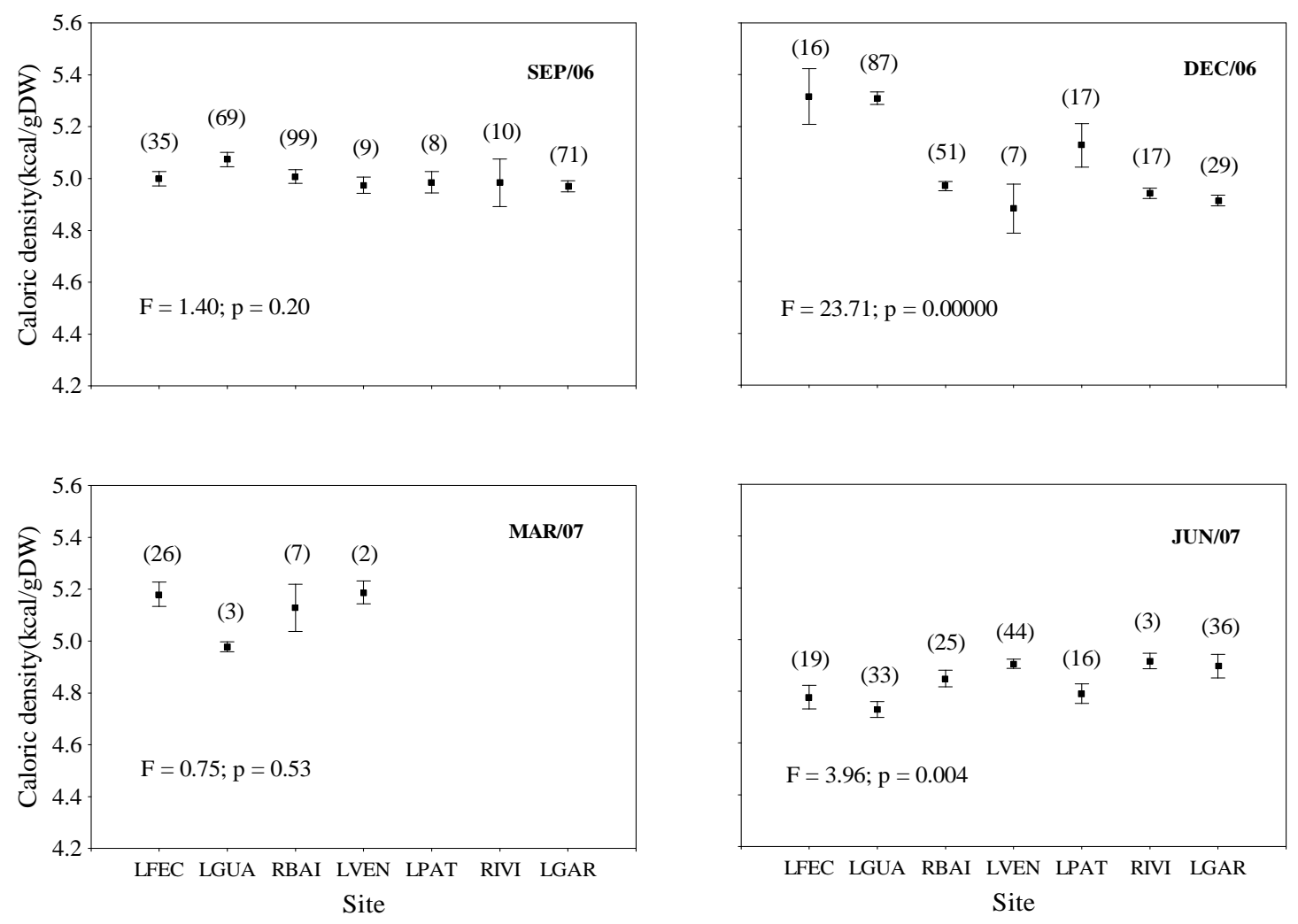

Figure 2 - Caloric average ( $\square$ ) \pm standard error (I) of the caloric density of Loricariichthys platymetopon, by site and month of collection, in the Upper Paraná River floodplain (number of sampled specimens in parentheses). LFEC = Fechada lake, LGUA = Guaraná lake, RBAI = Baía river, LVEN = Zé Ventura lake, LPAT = Patos lake, RIVI = Ivinhema river, and LGAR = Garças lake. 

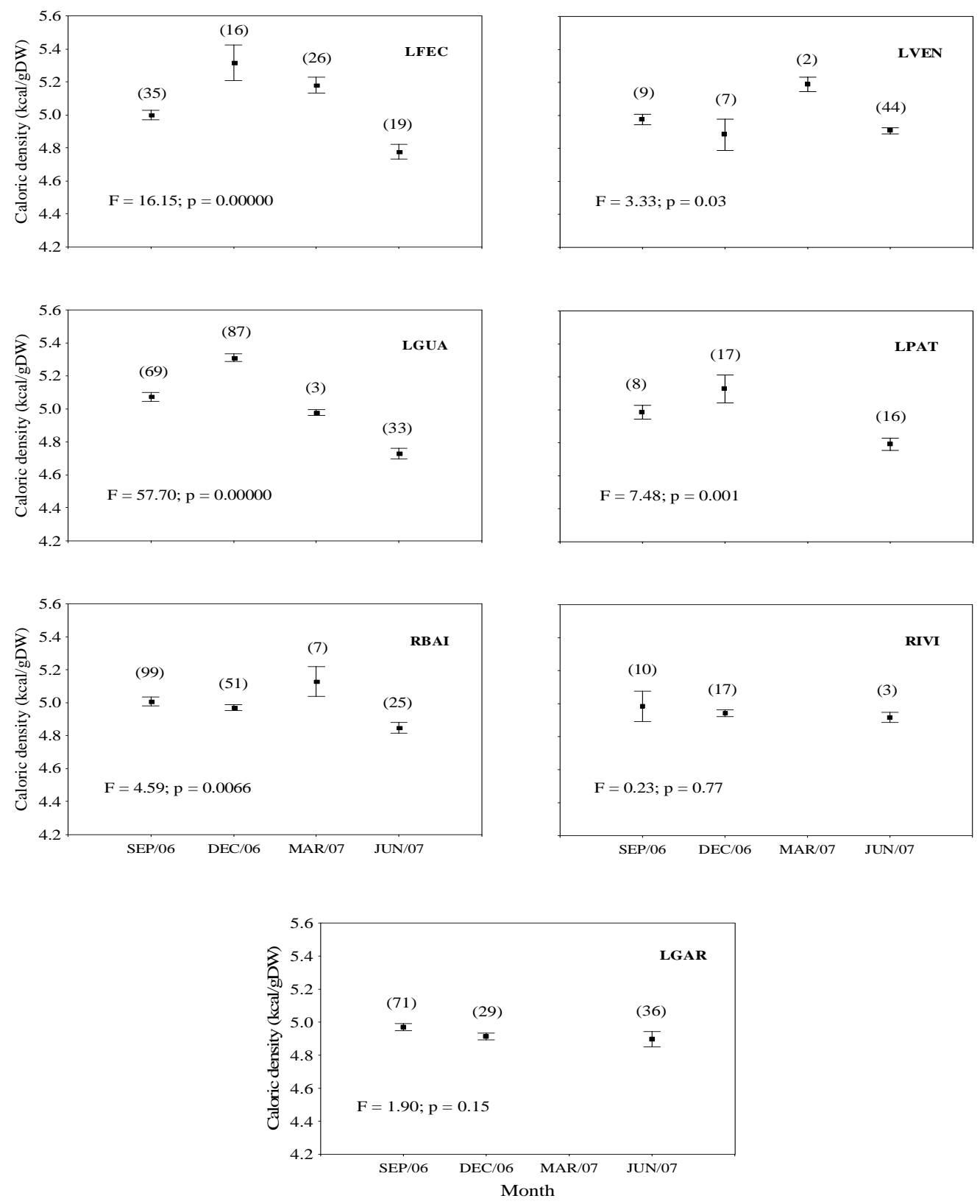

Figure 3 - Caloric average ( $\square) \pm$ standard error (I) of Loricariichthys platymetopon, by month and site of collection, in the Upper Paraná River floodplain (number of sampled specimens in parentheses).

\section{DISCUSSION}

The present study observed spatial variation in the caloric density of the muscles of $L$. platymetopon. In Manso reservoir this variation was also observed in neotropical species Serrassalmus maculatus, but not in Leporinus friderici, Acestrorhynchus pantaneiro, Schizodon borelli and Serrassalmus marginatus (Santana et al., 2005; Santos et al., 2006). Studies conducted with fish species from temperate regions indicate that the sites with greater food availability, higher energy content of food resources and lower intraspecific competition for those resources, tend to feature the individuals with better body energy conditions, that is, with higher caloric density. These are the factors responsible for spatial variation in the energy content of fish species in those regions (Hondorp et al., 2005; Buchheister et al., 2006; Pothoven et al., 2006). However, it was 
not possible in this study to explain why the caloric averages of $L$. platymetopon were highest at LFEC, LGUA and LPAT when compared to the other sampled sites in December 2006, and lowest in June 2007, because, the caloric density was not always similarly correlated (positively or negatively) with the variables food availability and relative numeric abundance of the studied species. Seasonal variability in caloric density of $L$. platymetopon was also registered in the present study, at most collection sites. For temperate and polar climate fish species, seasonal variations in body energy contents or parts of them are common. Temporal variability in food availability and intake, in diet, in the energy content of prey, in water temperature and in the reproductive cycle are among the factors that explain such seasonal variability (Kelso, 1973; Encina and GranadoLorencio, 1997; Hederson et al., 2000; Tirelli et al., 2006).

It was supposed that the seasonal variation trend at LPAT was identical to those at LFEC and LGUA. The same trend and closer proximity among the caloric average at these three sites were probably due to a greater environmental similarity among them, because the muscle caloric average of $L$. platymetopon was basically correlated with the same environmental variables (temperature, dissolved oxygen and percentage of organic matter) at these sites. The trends observed at LVEN, RIVI and LGAR were possibly similar to that recognized at RBAI, because at these sites the correlations among caloric density and environment and biological variables were not significant, and were weak at RBAI. The spatial heterogeneity that existed in the Upper Paraná River floodplain possibly contributed to the observation of these two seasonal variation trends. At the tropical regions, temperatures are generally more homogenous and higher than in temperate areas, and the variations are less pronounced (Esteves, 1998). However, the muscle caloric density of L. platymetopon was strongly correlated with the temperature at LGUA, LFEC and LPAT. At these sites, during months with higher temperatures, this species presented more energy in its muscles. However, the correlation between the muscle caloric density and water temperature was weak at RBAI and insignificant at LVEN, RIVI at LGAR.

Water temperature influences the behavioral and physiological processes of fish, acting directly on their metabolic rates (Wootton, 1990). It also has an important effect on food intake by fish (Padian and Vivekanadan, 1985). The decrease in water temperature can lead to lower food intake (Hederson et al., 2000), resulting in lower energy levels in fish muscles, because energy is transferred from the muscles in order to maintain metabolic activities. This could explain the lower levels of muscle energy in $L$. platymetopon during the winter (June 2007) at LGUA, LFEC and LPAT.

The negative correlations in muscle caloric density of L. platymetopon with dissolved oxygen in water at LGUA, LFEC, RBAI and LPAT indicated that the individuals of this species presented better muscle energy quality when subjected to lower concentrations of dissolved oxygen. However, food intake by fish is affected by the levels of dissolved oxygen in water (Jobling, 1994). This decline seemed not to interfere in food intake by $L$. platymetopon, possibly because this species featured a stomach that functioned as an accessory respiratory organ (Silva et al., 1997).

Loricariichthys platymetopon feeds mainly on large detritus (dead organic matter) particles in early stages of decomposition and certain amounts of benthic organisms associated with the detritus and sediment (Fugi et al., 2001). The positive correlation between the muscle caloric density and food availability recorded at LFEC and LGUA indicated that the energy condition of this species improved in so far as food availability increased at these sites. However, at RBAI and LPAT, this correlation was negative - as food availability increased, muscle caloric density decreased. The negative correlation mentioned above, could be explained if the energy quantity of the detritus consumed at these two sites (RBAI and LPAT) were taken into account. The percentage of organic matter in the sediment used in this study as an indicator of food availability in that environment reflected not only the amount of dead organic matter (detritus), but also live matter (benthic organisms), meaning that the increase in food availability for L. platymetopon could be the result of a higher concentration of these organisms in sediment and detritus, which might have reduced the energy quantity of the detritus consumed by this species at RBAI and LPAT.

This result corrobated the conceptual framework of throphic dynamic provided for Lindemann (1942) and Odum (1988). Hence, the dregree that the fish are subsidized by benthic resources may profoundly affect the pelagic communities 
(Vadeboncoeur et al., 2002) transferring variable amount of energy to the next throphic level.

The competition occurs when two or more individuals explore the same range of limited resources, and the intensity of the competition depends on the amount of food and the number of individuals that consume it at a given place and time (Brett and Groves, 1979; Jobling, 1994; (Pianka, 1994). In this study, the muscle caloric density of $L$. platymetopon was negatively correlated with the relative numeric abundance of the species at LFEC; as the number of individuals increased at that site, the muscle energy quality of those individuals decreased.

This increase in the abundance could result in a decrease in the food intake rate of each individual, if followed by a decrease or maintenance in food quantity in the environment. Therefore, at LFEC it was assumed that the food amount levels were correlated with the relative numeric abundance of L. platymetopon, negatively as well, thus intensifying the intraspecific competition for the food, which resulted in individuals with less energy in their muscles during certain periods. At LGUA, the opposite had probably occurred: a positive correlation between the abundance and food amounts, which led to less intraspecific competition, resulting in a positive correlation between the muscle caloric density and relative numeric abundance of the species in question.

In the present study, there was no significant correlation between the muscle caloric density of $L$. platymetopon and the gonadosomatic index, which allowed to infer that the energy quality of the muscle of this species was not affected by the reproductive cycle at any of the collection sites, different from what happened with some fish species, both temperate (Foltz and Norden, 1977; Eliassen and Vahl, 1982; Encina and GranadoLorencio, 1997; Hederson et al., 2000) and tropical (Santos et al., 2006; Monteiro et al., 2007).

The non-significant difference between the muscle caloric averages of different stages of gonadal development (in the males and females) confirmed that the muscles of $L$. platymetopon did not act as an accessory energy source for the growth and maturation of gonads, during the study period. The same was observed for the females of Schizodon borellii and Pimelodus maculatus (Doria and Andrian, 1997), females of Brycon hilarii, and both sexes of Hypophthalmus edentatus (Monteiro et al., 2007). However, Vismara et al. (2004) observed that gonadal maturation had an effect on the allocation of muscle energy of $L$. platymetopon in the Upper Paraná River floodplain, as opposed to what was observed in the present study. This effect had also been observed for the males of Serrassalmus marginatus, $S$. maculatus and Brycon hilarii at the Manso reservoir and adjacent area (Santos et al., 2006; Monteiro et al., 2007). When the energy demand associated with the reproduction (gonadal growth and maturation, secondary sexual traits and reproductive behavior) exceeds the energy provided by the available food, fish may use reserves present in the carcass and viscera, which accumulates when there is food in abundance (Foltz and Norden, 1977; Eliassen and Vahl, 1982; Jonsson et al., 1997).

The correlations between the muscle caloric density of L. platymetopon and body size were not significant. Some authors observed a positive correlation between these variables - larger fish featured higher caloric density than smaller fish (Paul et al., 1998; Tirelli et al., 2006). If a larger number of individuals of $L$. platymetopon belonging to the smaller classes of standard length had been sampled, the above-mentioned correlation would have been significant. In the maturation/juvenile stage, most of the assimilated energy is destined to the metabolism and somatic production (linear growth and development of somatic structures), leading to lower body energy density when compared with the adult fish. In the adult stage, more energy is directed to the reproductive and metabolic processes (storage of reserves and development of reproductive structures), with a reduction in the allocation of energy for somatic growth (Calow, 1985; Vazzoler, 1996). Thus, the present study was able to verify the occurrence of spatial and seasonal variation in the muscle caloric density of neotropical species Loricariichthys platymetopon in the Upper Paraná River floodplain, invalidating the use of constant values for this species. The intensity of the correlation between the caloric density and environmental variables (water temperature, dissolved oxygen in water, organic matter percentage and relative numeric abundance) varied according to collection site, as well as the form of correlation (organic matter percentage and relative numeric abundance). This was probably due to the greater complexity in the structure and functioning of tropical ecosystems compared to the temperate and polar environments. However, the body size and reproductive cycle of sampled 
individuals were not correlated with the muscle energy density of those individuals.

\section{ACKNOWLEDGEMENTS}

We wish to thank CNPq/CAPES/UEM for the financial and logistical support; the field and lab teams of project PELD (UEM-NUPELIA) for the help in collecting biological materials; the Graduate Program in Ecology of Continental Aquatic Environments (PEA-UEM); CAPES for the Masters scholarship; Jaime Luiz Lopes Pereira for devising the map; Maria Salete Ribellato Arita, João Fabio Hildebrandt and Márcia Regina Paiva for aiding in the bibliography review; Dr. Sidinei Magela Thomaz, biologist Maria do Carmo Roberto and Dr. Angelo Antonio Agostinho for making available biotic and abiotic data.

\section{RESUMO}

Este estudo analisou o conteúdo de energia (densidade calórica) de L. platymetopon capturados em diferentes locais da planície alagável do Alto Rio Paraná, e potenciais relações entre este conteúdo e várias variáveis ambientais (temperatura da água, oxigênio dissolvido na água, disponibilidade de alimento, abundância relativa numérica) e variáveis biológicas (tamanho corpóreo e ciclo reprodutivo). Coletas trimestrais, de setembro/2006 a junho/2007, em lagos e rios, resultaram em uma amostra de 739 espécimes, cuja densidade calórica muscular foi determinada através de calorímetro. Diferenças entre as médias calóricas de machos e fêmeas e entre os estádios de desenvolvimento gonadal não foram significativas Densidade calórica variou sazonal e espacialmente, com duas tendências de variação sazonal. A intensidade da correlação entre densidade calórica e cada variável e cada variável ambiental, assim como, a forma de correlação, variou de acordo com o local amostrado. Tamanho corpóreo e ciclo reprodutivo não estiveram correlacionados à densidade calórica.

\section{REFERENCES}

Brett, J. R. AND Groves, T. D. D. (1979), Physiological energetics. In - Fish Physiology, eds. W. S. Hoar, D. J. Randall and J. R. Brett. Academic Press, New York, pp. 280-352.
Bryan, S. D. et al. (1996), Caloric densities of three predatory fishes and their prey in Lake Oahe, South Dakota. J. Freshw. Ecol., 11, 153-161.

Bowen, S. H. (1983), Detritivory in neotropical fish communities. Environ. Biol. Fishes, 9, 137-144.

Buchheister, A. et al. (2006), Seasonal and geographic variation in condition of juvenile walleye pollock in the Western Gulf of Alaska. Trans. Am. Fish. Soc., 135, 897-907.

Calow, P. (1985), Adaptive aspects of energy allocation, In - Fish energetics: news perspectives, eds. P. Tytler and P. Calow. Croom Helm, Sydney, pp. 1-31.

Cui, Y. and Wootton, R. J. (1988), Effects of ration, temperature and body size on the body composition, energy content and condition of the minnow Phoxinus phoxinus (L.). J. Fish Biol., 32, 749-764.

Doria, C. R. and Andrian, I. F. (1997), Variation in energy content somatic and reproductive, tissues related to the reproductive cycle and feeding female Pimelodus maculates Lacépède, 1803 (Siluriformes, Pimelodidae) and Schizodon borelli Boulenger, 1895 (Characiformes, Anostomidae). Rev. UNIMAR, 9, 421-437.

Dourado, E. C. dos S. and Benedito-Cecilio, E. (2005), Ecologia energética de peixes: influência de fatores abióticos e bióticos. EDUEM, Maringá.

Dourado, E. C. dos S. et al. (2005), O grau de trofia do ambiente influencia a quantidade de energia dos peixes? In - Biocenoses em reservatórios: padrões espaciais e temporais, orgs. L. Rodrigues et al. RIMA, São Carlos, pp. 211-222.

Economidis, P. S. et al. (1981), Caloric content in some freshwater and marine fishes from Greece. Cybium, 5, 97-100.

Eliassen, J. E. and Vahl, O. (1982), Seasonal variations in biochemical composition and energy content of liver, gonad and muscle of mature and immature cod, Gadus morhua (L) from Balsfjorden, northern Norway. J. Fish Biol., 20, 707-716.

Encina, L. and Granado-Lorencio, C. (1997), Seasonal variations in the physiological status and energy content of somatic and reproductive tissues of chub. J. Fish Biol., 50, 511-522.

Esteves, F. A. (1988), Fundamentos de Limnologia. Interciência, Rio de Janeiro.

Foltz, J. W. and Norden, C. R. (1977), Seasonal changes in food consumption and energy content of smelt (Osmerus mordax) in Lake Michigan. Trans. Am. Fish. Soc., 106, 230-234.

Fugi, R. et al. (2001), Trophic morfology of five benthic-feeding fish species of a tropical floodplain. Rev. Bras. Biol., 61, 27-33.

Gaspar da Luz, K. D. et al. (2004), Fish assemblages in the Upper Paraná River floodplain. In - Structure and functioning of the Paraná River and its floodplain: LTER - site 6, eds. A. A. Agostinho et al. EDUEM: NUPELIA, Maringá, pp. 107-115. 
Gotelli, N. J. and Entsminger, G. L. (2007), EcoSim: Null models software for ecology. Version 7. Acquired Intelligence Inc. and Kesey-Bear. Jericho, VT $05465 . \quad$ Disponível em <http://garyentsminger.com/ecosim.htm>. Acesso em 25 fev. 2008.

Hansen et al. (1993), Applications of bioenergetics models to fish ecology and management: Where do we go from here? Trans. Am. Fish. Soc., 122, 10191030 .

Henderson, B. A. et al. (2000), Annual cycle of energy allocation to growth and reproduction of yellow perch. J. Fish Biol., 57, 122-133.

Hondorp, D. W. et al. (2005), Influence of Diporeia density on diet composition, relative abundance, and energy density of planktivorous fishes in southeast Lake Michigan. Trans. Am. Fish. Soc., 134, 588-601.

Isbrücker, I. J. H. and Nijssen, H. (1979), Three new south american mailed catfishes of the genera Rineloricaria and Loricariichthys (Pisces, Siluriformes, Loricariidae). Bijdr. Dierkd., 48, 151211.

Jobling, M. (1994), Fish bioenergetics. Chapman and Hall, London.

Jonsson, N. et al. (1997), Changes in proximate composition and estimates of energetic costs during upstream migration and spawning in Atlantic salmon Salmo salar. J. Anim. Ecol., 66: 425-436.

Kelso, J. R. M. (1973), Seasonal energy changes in walleye and their diet in West Blue Lake, Manitoba. Trans. Amer. Fish. Soc., 102, 363-368.

Lindeman, R. L. (1942), The trophic dynamic aspect $\mathrm{f}$ ecology. Ecology, 23, 399-418.

Monteiro, V. et al. (2007), Efeito da estratégia de vida sobre as variações no conteúdo de energia de duas espécies de peixes (Brycon hilarii e Hypophtalmus edentatus), durante o ciclo reprodutivo. Acta Sci., 29, 151-159.

Odum, E. P. (1988), Ecologia. Editora Guanabara, Rio de Janeiro.

Pandian, T. J. and Vivekanandan, E. (1985). Energetics of feeding and digestion. In - Fish energertics: news perpectives, eds. P. Tytler and P. Calow. Croom Helm, Sydney, pp. 99-124.

Paul, A. J. et al. (1998), Fall and spring somatic energy content for Alaskan Pacific herring (Clupea pallasi Valenciennes 1847) relative to age, size and sex. $J$. Exp. Mar. Biol. Ecol., 223,133-142.

Pedersen, J. and Hislop, J. R. G. (2001), Seasonal variation in the energy density of fishes in the North Sea. J. Fish Biol., 59, 380-389.

Pianka, R. E. (1994), Evolutionary ecology. Harper Collins, New York.

Pothoven, S. A. et al. (2006), Energy density of lake whitefish Coregonus clupeaformis in Lakes Huron and Michigan. Environ. Biol. Fishes, 76, 151-158.
Reis, R. E. and Pereira, E. H. L. (2000), Three new species of the Loricariid catfish genus Loricariichthys (Teleostei: Siluriformes) from the Southern South America. Copeia, (4), 1029-1047.

Reis, R. E. et al. (2003), Check list of the freshwater fishes of South and Central America. EDIPUCRIS, Porto Alegre.

Rogers, S. I. (1988), The seasonal partitioning of energy in an estuarine fish, the common goby, Pomatoschistus microps Krøyer. J. Fish Biol., 33, 4550.

Santana, A. R. A. et al. (2005), Conteúdo energético de peixes do reservatório do rio Manso: variações espaciais e por grupo trófico. Acta Sci. Biol. Sci., 27, 391-395.

Santos, M. H. dos et al. (2006), Efeito da maturação gonadal sobre a energia dos músculos de duas espécies de piranhas do reservatório do rio Manso, MT. Acta Sci. Biol. Sci., 28, 227-236.

Silva, J. M. et al. (1997). A new accessory respiratory organ in fishes: morphology of the respiratory purses of Loricariichthys platymetopon (Pisces, Loricariidae). Ann. Sci. Natur. Zool., 18, 93-103.

Tirelli, V. et al. (2006), Energy density of anchovy Engraulis encrasicolus L. in the Adriatic Sea. J. Fish Biol., 68, 982-989.

Thomaz, S. M. et al. (1997), Caracterização limnológica dos ambientes aquáticos e influência dos níveis fluviométricos. In - A planície de inundação do alto rio Paraná: aspectos físicos, biológicos e socioeconômicos, eds. A. E. A. M. Vazzoler et al. EDUEM: NUPELIA, Maringá, pp. 73-102.

Thomaz, S. M. et al. (2004), Limnological characterization of the aquatic environments and the influence of hydrometric levels. In - The Upper Paraná River and its floodplain: physical aspects, ecology and conservation, eds. S. M. Thomaz et al. Backhuys Publishers, Leiden, pp. 75-102.

Wootton, R. J. (1990), Ecology of teleost fishes. Chapman and Hall, London.

Vadeboncouer, Y. et al. (2002), Putting the lake back together: reintegrating benthic pathways into lake food web models. Bioscience, 51, 44-54.

Vazzoler, A. E. A. de M. (1996), Biologia da reprodução de peixes teleósteos: teoria e prática. EDUEM: NUPELIA, Maringá, SBI, São Paulo.

Vismara, M. R. et al. (2004), Efeito da maturação gonadal sobre o conteúdo calórico e condição geral de peixes da planície de inundação do alto rio Paraná. Acta Sci., 26, 189-199. 